\title{
Customer Satisfaction towards Nandi Pipes Pvt Ltd: A Case Study In Chittoor In Andhra Pradesh
}

\author{
Dr. Duggani Yuvaraju (PDF- Scholar), Dr. D.Subramanyam, \\ Prof. S. Durga Rao \\ Department of Management Studies, S.V. University, Tirupati- 517502. \\ Dept of economics, s.v.university, tirupati-517502, \\ Department of Management Studies, S.V. University, Tirupati- 517502.
}

\begin{abstract}
Customer satisfaction, a business term, is a measure of how products and services supplied by a company meet or surpass customer expectation. We found that the majority of respondents are preferred quality, quantity, price and availability of Nandi pipes, are influenced by mouth publicity, news papers, A.P.S.R.T.C Buses and televisions factors in their purchasing of Nandi pipes, $28 \%$ of respondents are satisfied and few of respondents are not satisfied with the delivery of Nandi pipes, Company adopted a common credit policy for all customers to exchange the product, majority customers using Nandi pipes and few customers are using competitor's pipes (Sudhakar, Monarch).
\end{abstract}

\section{Introduction}

Customer satisfaction, a business term, is a measure of how products and services supplied by a company meet or surpass customer expectation. It is seen as a key performance indicator with in business. In a competitive market place where businesses compete for customers, customer satisfaction is seen as a key differentiator and increasingly has become a key element. Satisfaction is a person's feeling of pleasure or disappointment resulting from comparing a product is perceived performance (outcome) in relation to his or her expectations. As this definition makes clear, satisfaction is a function of perceived performance and expectations, if the performance falls short of expectations, the customer is dissatisfied, if the performance exceeds the expectations, the customers are highly satisfied (or) delighted. Many companies are aiming for high satisfaction because customers who are just satisfied are still find it easy to switch when a better offer comes along, those who are highly satisfied are much less ready to switch. High Satisfaction or delight creates an emotional affinity with the brand, not just a rational performance. The result is high customer loyalty.

Growth of Nandi Pipes Pvt Ltd: Nandi pipes Pvt. Ltd. is commissioned with the objectives of catering to the agricultural needs of the region. In earlier days, tools used for Water flow were very ineffective with high percentage of seepage losses. To counter this draw back PVC pipes were favourably welcomed, this has been the mission of Nandi pipes Pvt Ltd. the Major irritants in agricultural practices like lack of rainfall. Ground water lifting water transport with in the fields has provided magnificent thrust to HDPE pipes market. These factors helped Nandi Pipes Pvt. Ltd, to record an excellent growth since 1977 onwards. Quality is the dominating factor in the growth of Sales. Well-equipped Laboratory and quality control office looks after the quality. The company not only improving the brand name but also it is undertaking takeover of the competitor's brands. In 1977 the company takes over the sagar brand. The manufacturing plant of sagar brand was at Medak District. The Nandi Pipes Company not slopped with that victory, the company over another main competitor's brand Monarch in 1999. The manufacturing plant of Monarch plant lines at Ananthapur.

Quality: Quality is the dominating factor in the growth of sales. Well-equipped and quality laboratory and quality control office looks after the quality.

Brand name: Out of five varieties of products offered by the organization, Nandyal Nandi pipes has got excellent local popularity as it symbolizes the region and the sacred bull. The remaining live got their impact in other states.

Sizes: Various sizes ranging from "1/2 to 10 " inches offered to customers. But for the purpose of cubic space utilization in trucks while a sport organization is adopting the technique like pipe in pipe.

Warranties: No written warranties are given to customers expect an assurance that the product is reliable

Payment period: Zero credit policy is adopted by the company and goods are not delivered unless cash remittance is made. The same policy is also applicable to authorize customers of Nandi Pipes Pvt. Ltd.., We believe that companies are about people more than anything else is. The group companies employ about 1500 people. Free accommodation is provided to most of the employees. Health services are also provided at free of cost. Other business interests of Nandi group include dairy product, information technology and education 
Nandi Pipes (p) Ltd, manufacturers the largest and most comprehensive range of HDPE pipes in India. They offer pipes of up to $400 \mathrm{~mm}$ diameter Nandi pipes that are suitable for a wide range of applications.

Portable water transportation, irrigation, plumbing, drainage, cable ducting bore-wells, transfer of industrial effluents. Our gamuts of products cover all applications, which are covered by PVC Pipes. Nandi HDPE systems are more cost effective than conventional GI, CI or AC systems. They are lightweight, durable and noncorrosive. They offer excellent flow characteristics and they are easy to transport handle and install as well. Excellent quality with customized product development support. Canal irrigation is one such method. However, canals occupy cultivate space and thus hamper production. Moreover, nearly $40 \%$ of canal water is wasted due to evaporation and percolation. Besides, in certain areas, canal irrigation, over a period, has led to salivations. Pipes are an effective way of overcoming the problem caused by canal irrigation as they can be laid underground and water loss because of percolation and evaporation is eliminated. Lift irrigation is employed to carry water from a lower to a higher level. Here, various kinds of pipes are used.

\section{Review of literature}

Dr.N.Chandrasekaran investigated the wants of the customer are carefully studied by conducting surveys on consumer behavior. The study also helps to know various marketing variables such as price and product features. This study will help gain knowledge about the influence of consumer to prefer a particular brand and the problems faced by them using such brands.

Dr.S.K.Sinha \&Ajay Wagh examined that India is one of the fastest growing telecommunication markets of the twenty first century. The common man, artisans, agricultural labours, vendors and workers from every walk of life are comfortably using the services provided by telecom industries. The potential of capturing market segment will surely depend upon understanding dynamics of customer's preference.

According to Lewis \&Boom service quality is considered as a measure of how well the service delivered matches customers expectations on providing a better service than the customer expect organizational brand promotional strategies should be based on developing innovative offers \& products, developing cost friendly value driven packages and tariffs, offering quality services after sales service $\&$ ability to make calls without getting cut off \&also to provide cheaper cost of calls to other networks.

Dr. C. Annandan \& M. Prasanna Mohan Raj \& Mr. S. Madhu examined the new mantra of all FMCG giants is; To get rich, sell to the rural,. So they have started marketing programs to explore the untapped segment of rural markets. As far as FMCG is concerned, the market penetration and consumption in rural areas is low so there is an opportunity for marketers to utilize the market effectively. Another key positive aspect is the current government focuses on rural areas. Understanding the rural customers. Inadequate data on rural markets. Reaching of products or services to 6.4 lakhs villages for poor infrastructure facility.

Rachel Dardis, Horacio Soberon-Ferrer investigated the consumer decision making is multinational, that is consumer choices are not base on a single product attributes, instead consumers view products as bundles of attributes. Product attributes (automobile attributes) as well as household characteristics. In both instances, the higher the value of the cost index or the Trouble Index, the more unsatisfactory the car is relative to other cars. A better educated household might be more informed about the performance properties of Japanese cars and attracted by the higher value reliability of these cars.

\section{Need For The Study}

In the context of developing agriculture lent role of Nandi pipes for irrigation has been increasing every day. At the same time numbers of manufactures are increased in this segment. So in order to assess the customer satisfaction in the PVC pipes market research is undertakes. It is beneficial for the company to design their future developments and for identifying the pitfalls in the market.

\section{Objectives Of The Study}

- $\quad$ To find out the customer satisfaction levels towards Nandi HDPE pipes.

- To suggest the NANDI Polymers to enhance its customer's satisfaction levels.

\section{Methodology}

Data sources:

Secondary data:

Secondary data is collected from the literature survey like company records, broachers, CRM book Werner J.Reinartz and Philip Kotler websites.

\section{Primary data:}

Primary data is collected from the customers through structured questionnaire. 
$\begin{array}{lll}\text { Research design } & : & \text { descriptive research } \\ \text { Research approach } & : & \text { survey method } \\ \text { Research instrument } & : & \text { questionnaire }\end{array}$

\section{SAMPLING PLAN:}

Sampling unit

Sampling size

Sampling technique

Statistical tool

$\begin{array}{ll}: & \text { customers of Nandi pipes } \\ : & 100 \\ : & \text { convenience sampling } \\ : & \text { Pie charts and graphs }\end{array}$

IV. Data Analysis \& Interpretation

\begin{tabular}{|l|l|l|}
\hline Table -1: Regular Customers of Nandi Pipes \\
\hline & No. of Respondents & Percentage (\%) \\
\hline Yes & 82 & $82 \%$ \\
\hline No & 18 & $18 \%$ \\
\hline
\end{tabular}

Graph

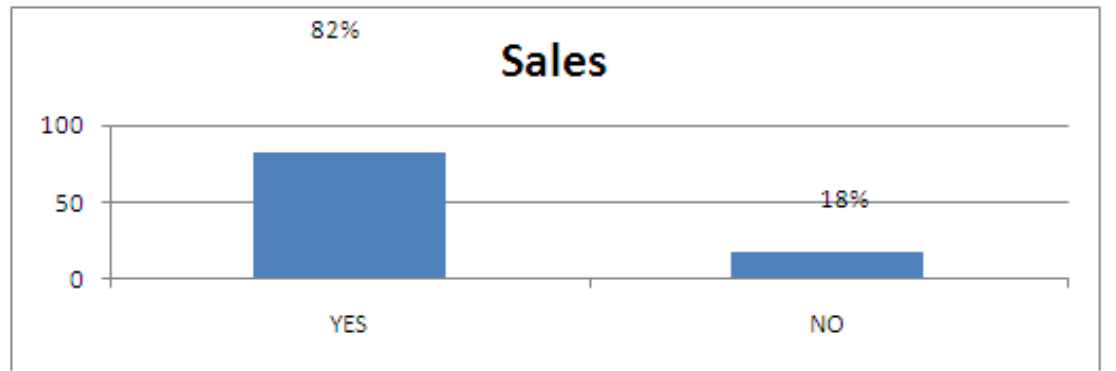

Interpretation: The above the graph clearly shows $82 \%$ respondents are using the Nandi pipes and $18 \%$ of respondents using other brands.

\begin{tabular}{|l|l|l|}
\hline \multicolumn{3}{|c|}{ Table - 2: How many years are you using Nandi Pipes } \\
\hline Years & No. of Respondents & Percentage (\%) \\
\hline Less than 1 year & 34 & $34 \%$ \\
\hline 1-5years & 26 & $26 \%$ \\
\hline 5-10years & 29 & $29 \%$ \\
\hline More than 10years & 11 & $11 \%$ \\
\hline
\end{tabular}

Graph

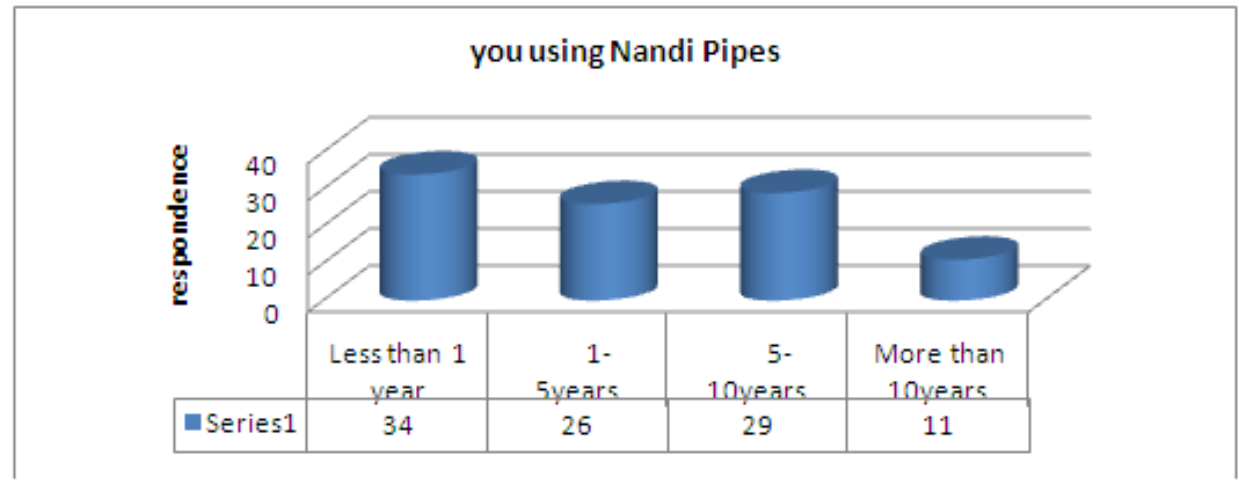

Interpretation: The above graph clearly shows indicate that $43 \%$ of the respondents are using 5-10 years , $27 \%$ of respondents are using more than 10 years and follows.

\begin{tabular}{|l|l|l|}
\hline \multicolumn{2}{|c|}{ Table -3: Awareness on Competitive Brands } \\
\hline & Respondents & Percentage $\%$ \\
\hline Yes & 70 & $70 \%$ \\
\hline No & 30 & $30 \%$ \\
\hline
\end{tabular}




\section{Graph}

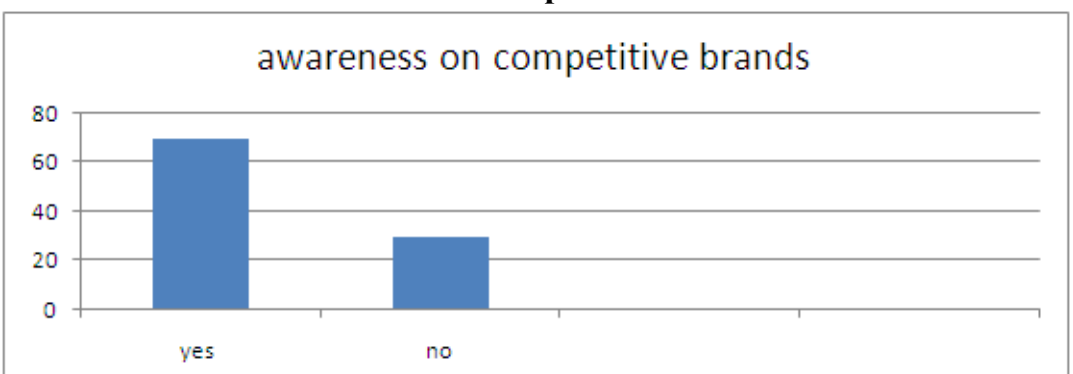

Interpretation: The above graph Clearly show that results shows that $60 \%$ respondents are not aware of competitive brands, $40 \%$ of respondents are competitive brands.

\begin{tabular}{|l|l|l|}
\hline \multicolumn{2}{|c|}{ Table - 4: How Do You Came to Knowing About Nandi Pipes } \\
\hline & Respondents & Percentage\% \\
\hline Dealers & 23 & $23 \%$ \\
\hline Reference & 56 & $56 \%$ \\
\hline Commercial ads & 18 & $18 \%$ \\
\hline Others & 3 & $3 \%$ \\
\hline
\end{tabular}

\section{Graph}

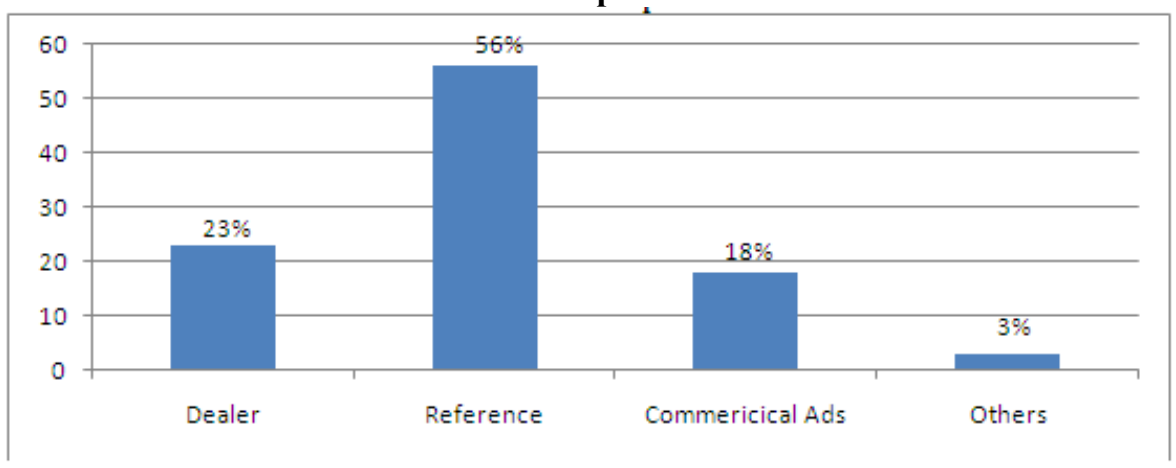

Interpretation: The above graph shows that $23 \%$ of respondents are reasoned through Dealer and $56 \%$ of respondents are reference and $18 \%$ of respondent's commercials and $3 \%$ of the respondents are others.

\begin{tabular}{|l|l|l|}
\hline \multicolumn{3}{|c|}{ Table -5 Opinion on Quality Standards of Nandi Pipes } \\
\hline Satisfaction & No. of Respondents & Percentage (\%) \\
\hline Very much satisfaction & 60 & $60 \%$ \\
\hline Satisfied & 37 & $37 \%$ \\
\hline Dissatisfaction & 7 & $7 \%$ \\
\hline Very much Dissatisfaction & 3 & $3 \%$ \\
\hline
\end{tabular}

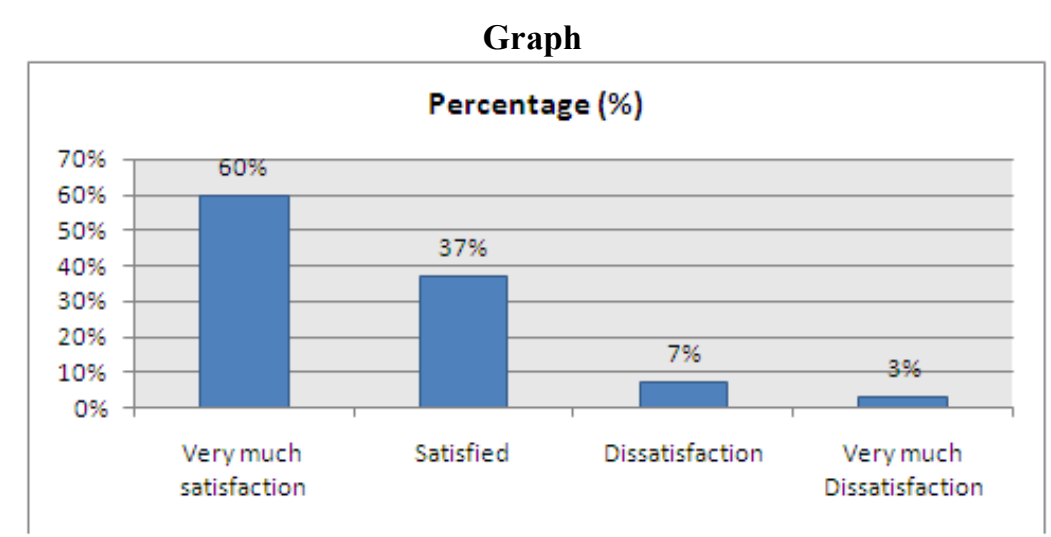

Interpretation: The above graph shows that $60 \%$ of respondents are Very much satisfied, and $37 \%$ of respondents are satisfied, and 7\% of Respondents are Dis- satisfied and 3\% of respondents are the Very much dis-satisfied with the quality \& performance of Nandi 


\begin{tabular}{|l|l|l|}
\hline \multicolumn{2}{|c|}{ Table -6: Opinion on Durability of Nandi Pipes } \\
\hline & Respondents & Percentage \\
\hline Yes & 68 & $68 \%$ \\
\hline No & 32 & $32 \%$ \\
\hline
\end{tabular}

\section{Graph}

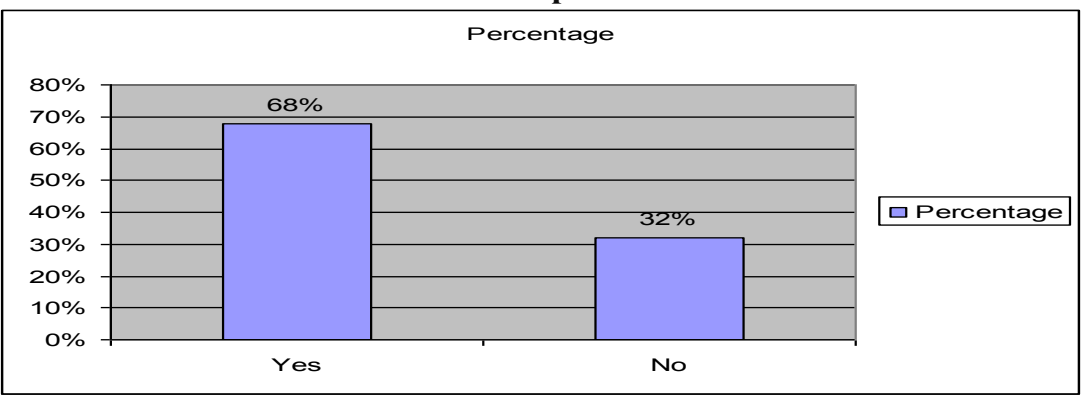

Interpretation: The above graph shows that $68 \%$ of respondents are YES and $32 \%$ of respondents are NO, with the durability of Nandi Pipes.

\begin{tabular}{|l|l|l|}
\hline \multicolumn{2}{|c|}{ Table - 7: Opinion on Service of Nandi Pipes } \\
\hline & Respondents & Percentage\% \\
\hline Good & 55 & $55 \%$ \\
\hline Average & 23 & $23 \%$ \\
\hline Excellent & 18 & $18 \%$ \\
\hline Poor & 4 & $4 \%$ \\
\hline
\end{tabular}

\section{Graph}

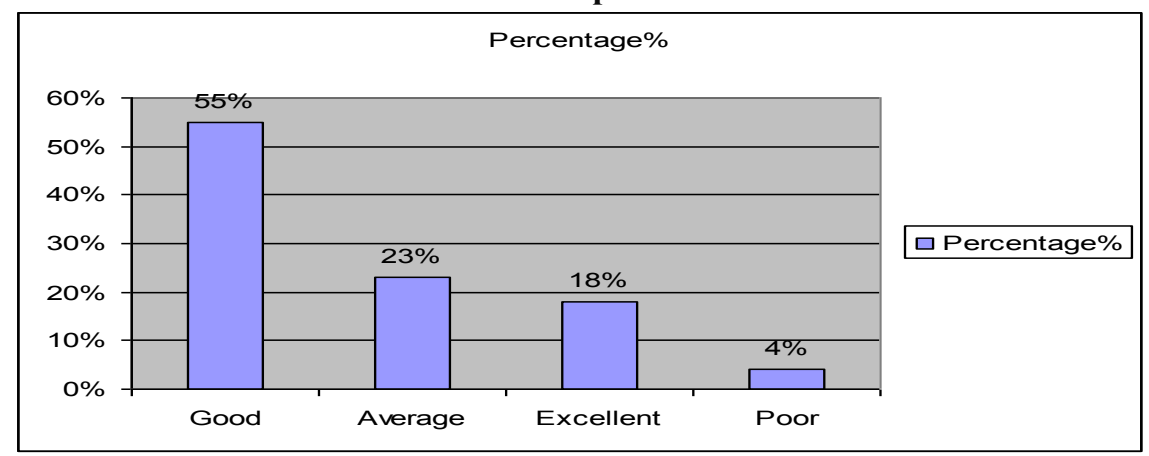

Interpretation: The above graph shows that the $55 \%$ of Respondents tells that good, $23 \%$ of respondents tells that average, $18 \%$ of respondents are Excellence , $4 \%$ of respondents is poor with the service of Nandi pipes.

\begin{tabular}{|l|l|l|}
\hline \multicolumn{3}{|c|}{ Table - 8: Opinion on Delivery of Nandi Pipes } \\
\hline & Respondents & Percentage\% \\
\hline Yes & 80 & $80 \%$ \\
\hline No & 20 & $20 \%$ \\
\hline
\end{tabular}

\section{Graph}

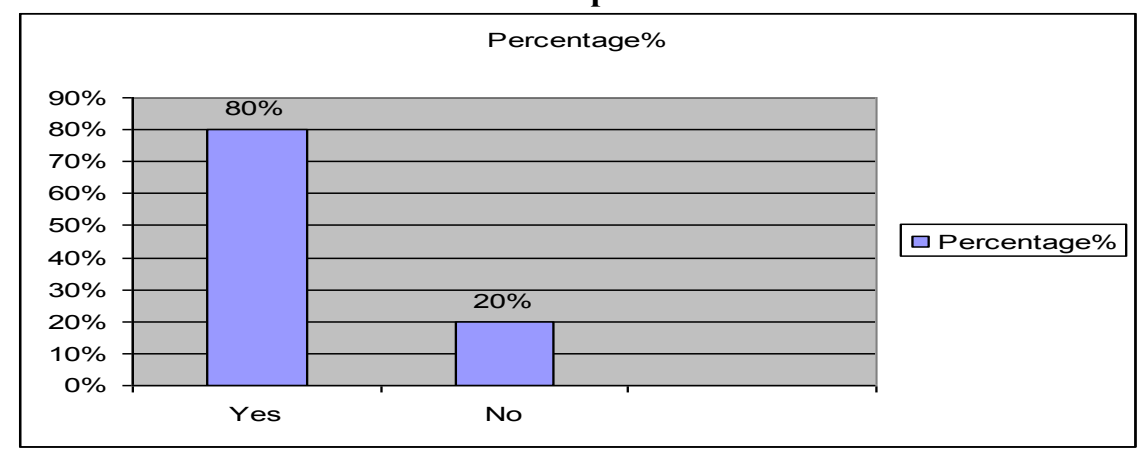

Interpretation: The above tabulated result shows that $80 \%$ of respondents are satisfied, $20 \%$ of respondents are not satisfied with the delivery of Nandi pipes. 


\begin{tabular}{|l|l|l|}
\hline \multicolumn{2}{|c|}{ Table - 9: Opinion on After Sales Service of Nandi Pipes } \\
\hline & Respondents & Percentage \\
\hline Can't say & 59 & $59 \%$ \\
\hline Satisfied & 28 & $28 \%$ \\
\hline Not satisfied & 13 & $13 \%$ \\
\hline
\end{tabular}

\section{Graph}

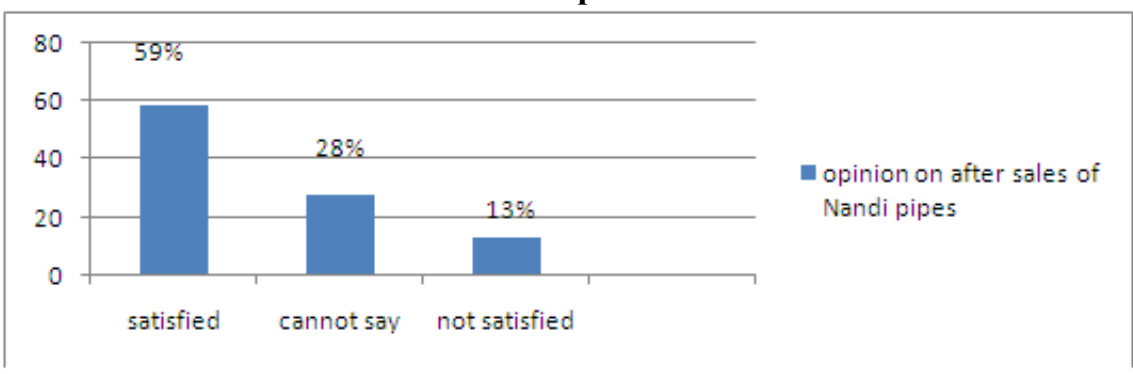

Interpretation: The above graph shows that $59 \%$ of respondents are can't say, $28 \%$ of respondents are satisfied, and $13 \%$ of respondents are not satisfied with after sales service of Nandi pipes.

\begin{tabular}{|l|l|l|}
\hline \multicolumn{2}{|c|}{ Table - 10. What Are The Attributes That You Like In Nandi Pipes } \\
\hline Types & Respondents & Percentage \\
\hline Reasonable price & 24 & $24 \%$ \\
\hline Durability & 10 & $10 \%$ \\
\hline Quality & 39 & $39 \%$ \\
\hline Services & 27 & $27 \%$ \\
\hline
\end{tabular}

\section{Graph}

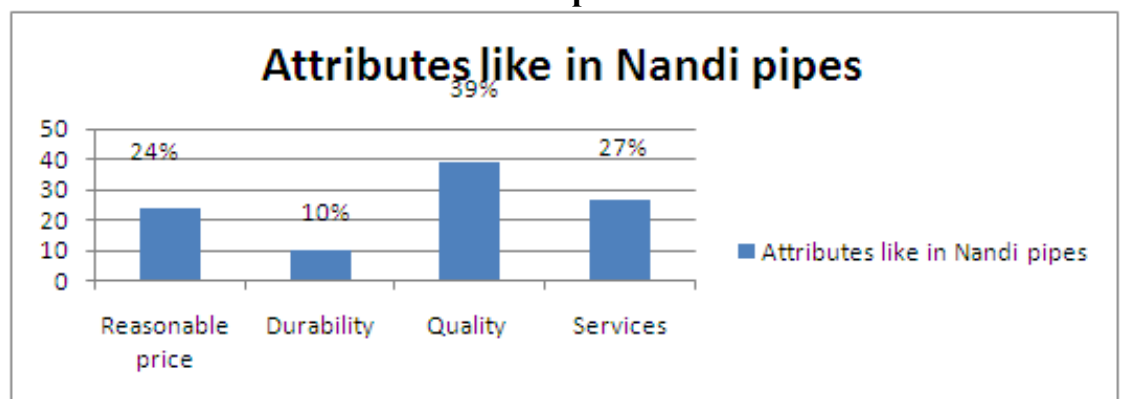

Interpretation: The above graph shows $24 \%$ of respondents are Reasonable price $10 \%$ of respondents are Durability $39 \%$ of respondents are quality $27 \%$ of respondents are services.

\begin{tabular}{|l|l|l|}
\hline \multicolumn{3}{|c|}{ Table - 11: Opinion on Offers And Discount of Nandi Pipes? } \\
\hline & Respondents & Percentage \\
\hline YES & 68 & $68 \%$ \\
\hline NO & 32 & $32 \%$ \\
\hline
\end{tabular}

\section{Graph}

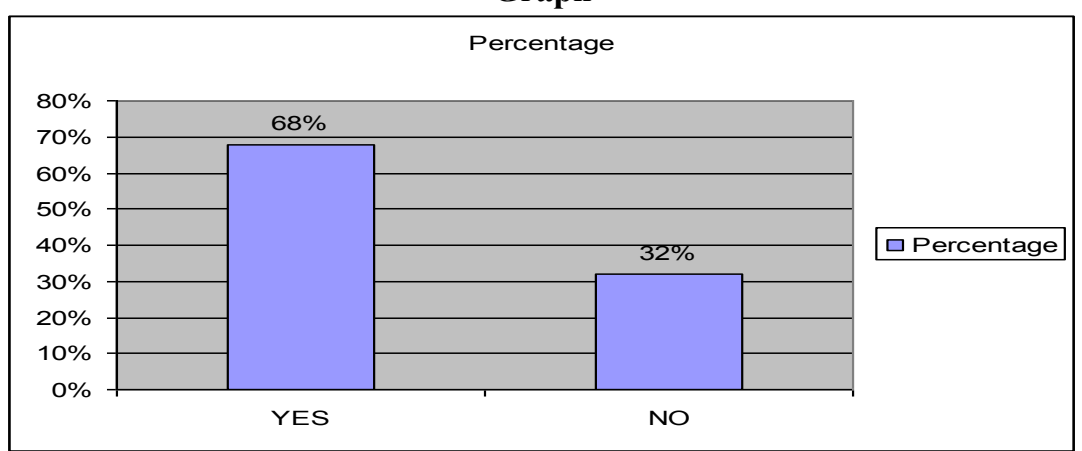

Interpretation: The above graph shows that $68 \%$ of respondents are satisfied, $32 \%$ of respondents are not satisfied with the offers and discounts of Nandi pipes. 


\begin{tabular}{|l|l|l|}
\hline \multicolumn{3}{|c|}{ Table - 12: Recommendations of Nandi Pipes } \\
\hline & Respondents & Percentage \\
\hline SURE & 75 & $75 \%$ \\
\hline CAN'T SAY & 22 & $22 \%$ \\
\hline NO & 3 & $3 \%$ \\
\hline
\end{tabular}

\section{Graph}

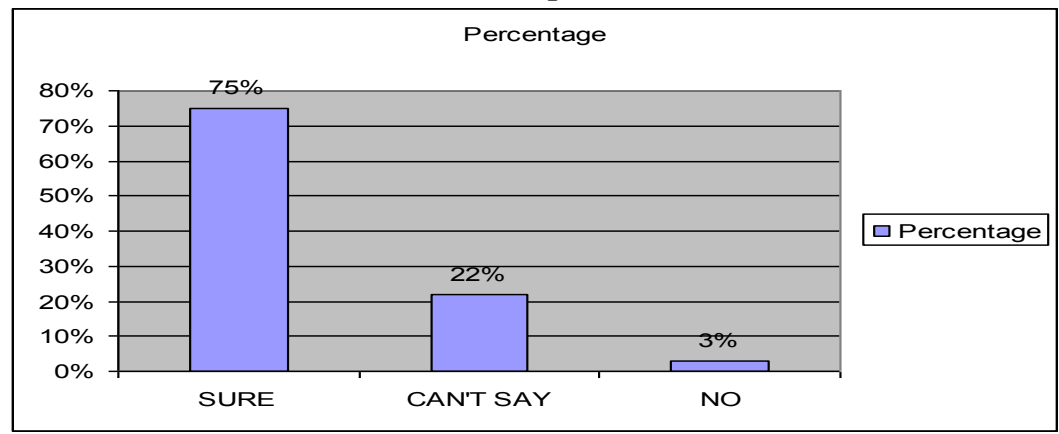

Interpretation: The above graph shows that $75 \%$ of respondents are recommends, $22 \%$ respondents are can't say, and 3\% of respondents are not recommends with the using of the Nandi pipes.

\begin{tabular}{|l|l|l|}
\hline \multicolumn{2}{|c|}{ Table - 13: Which company provided better services? } \\
\hline Types & No. of Respondents & Percentage \\
\hline Sudhaker & 31 & $31 \%$ \\
\hline Nandi & 42 & $42 \%$ \\
\hline Monarch & 13 & $13 \%$ \\
\hline Finolax & 14 & $14 \%$ \\
\hline
\end{tabular}

\section{Graph}

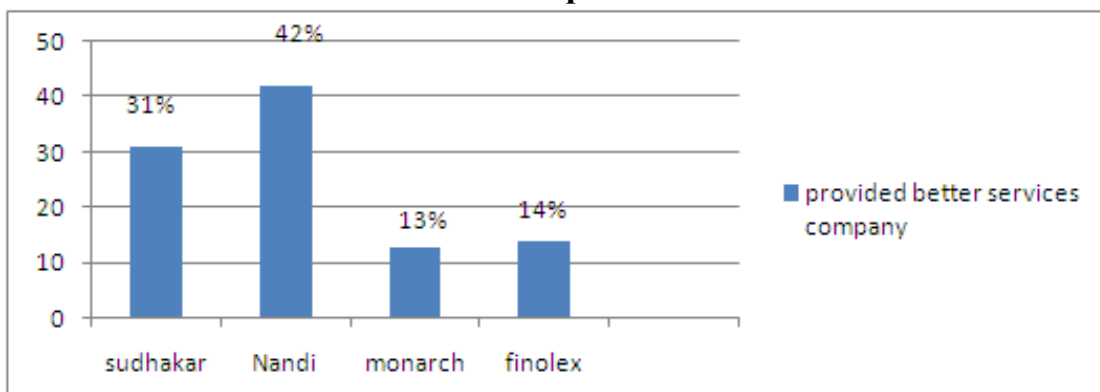

Interpretation: Above graph shows that $31 \%$ of respondents frequently purchase Sudakar pipes, $42 \%$ of respondents purchase Nandi pipes, $13 \%$ of respondents purchase of Monarch pipes, $14 \%$ of respondents purchase Finolax pipes.

\begin{tabular}{|l|l|l|}
\hline \multicolumn{2}{|c|}{ Table -14: Opinion on Price of Nandi Pipes } \\
\hline & No. of Respondents & Percentage \\
\hline Higher & 33 & $33 \%$ \\
\hline Reasonable & 58 & $58 \%$ \\
\hline Lower & 9 & $9 \%$ \\
\hline
\end{tabular}

\section{Graph}

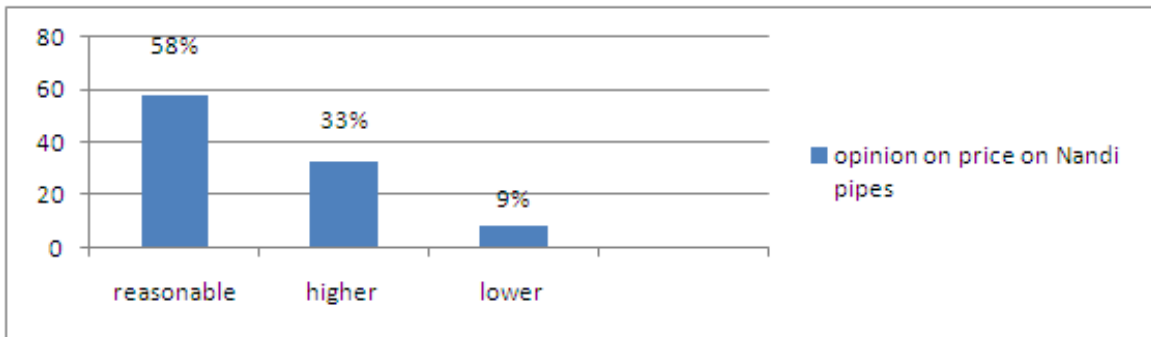

Interpretation: Above graph shows the opinions of 58\% 0f respondents are higher and, $33 \%$ of respondents are reasonable, $9 \%$ of respondents are lower. 


\begin{tabular}{|l|l|l|}
\hline \multicolumn{3}{|c|}{ Table -15: Are getting solution for your problems regarding Nandi pipes } \\
\hline \multicolumn{2}{|c|}{ No. of Respondents } & Percentage \\
\hline Yes & 69 & $69 \%$ \\
\hline No & 31 & $31 \%$ \\
\hline
\end{tabular}

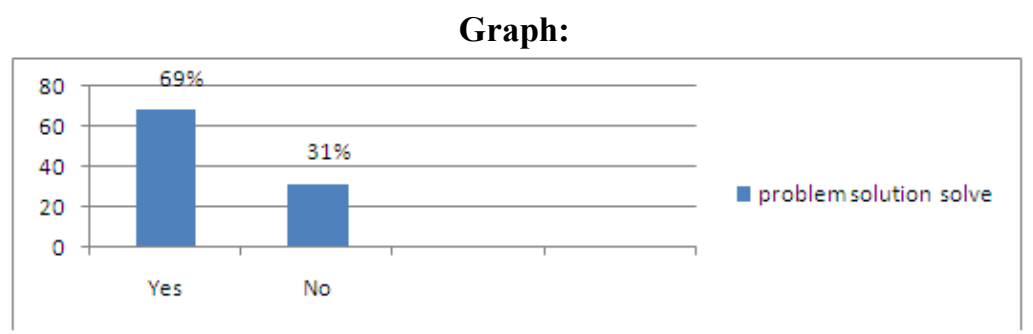

Interpretation: Above graph shows the opinions of $69 \%$ of respondents are yes and, $31 \%$ of respondents are no solution for your problems.

\section{Findings}

It is found that majority of respondents are preferred quality, quantity, price and availability of Nandi pipes.

- According to my view it is found that majority of respondents are influenced by mouth publicity, news papers, and A.P.S.R.T.C Buses and televisions factors in their purchasing of Nandi pipes.

- It is found that majority of customers are satisfied and few of customers are not satisfied with the delivery of Nandi pipes.

- Company adopted a common credit policy for all customers to exchange the product.

- It is found that majority customers using Nandi pipes and few customers are using competitor's pipes (Sudhakar, Monarch).

\section{Suggestions}

- Company need to maintain the same level services with related to price, quality, quantity, availability etc.,

- In newly open Nandi points advertising though palm plates would be more effective.

- Company need to expand customer network to increase the access of the product to the customers.

- If the company provide small incentives to the customers like competitors are distributing the calendar. They may be a chance to show interest to purchase the pipes.

- Most of Nandi points located in narrow loans of the street therefore print media of the showing of the address of the Nandi points would be better.

\section{Conclusion}

- The study concludes that Nandi Pipes are upcoming brand and customers are satisfied with quality of the Pipe, discount rates and delivery. But the respondents are not much satisfied with their sales of service.

- A supplier should always keep on improving so as to achieve a greater profitability. This can be achieved by knowing the market well, i.e. understanding exactly what the customer wants. By discovering what the customer wants, the supplier can being to understanding how his products and services provide value for his customers.

- A simple tool is to take customer satisfaction surveys and analyze the customer feedback. This gives the supplier an insight on where he lacks in delivering his products or services and where is the scope of improvement.

\section{References}

[1]. Chopra, Sunil and Peter Meindl, 2001, Customer Satisfaction: Strategy, Planning and Operations, Prentice-Hall Inc.

[2]. Fredendall, Lawrence D. and Ed Hill, 2001, Basics of Supply Chain Management, St. Lucie Press.

[3]. Council of Logistics Management, www.clm1.org

[4]. Integrated Business Communications Alliance, www.ibcaweb.org

[5]. www.cio.com/research/scm

[6]. www.nandipipes.com

[7]. Dr.C.Annandan \& M.Prasanna Mohan Raj \& Mr.S.Madhu, A Study on Brand preference of washing soaps in rural areas, Indian Journal of marketing,March 2007, Page no-30

[8]. Dr.N.Chandrasekaran, Consumer Behaviour and Brand Preference towards Onida Television - An Empirical Study with Reference to Karur, Tamilnadu, Indian Journal of Marketing, July 2009,Page No-58

[9]. Dr.S.K.Sinha \&Ajay Wagh, Analysing growth of cellular telecom sector and consumer's understanding preferences and choices on the use of cell phone-Indian Journal of Marketing. Sep 2008 Page no -2

[10]. Rachel Dardis, Horacio Soberon-Ferrer, consumer's preferences for Japanese auto mobiles, Journal of consumer affairs, summer 1994

[11]. Hugos, Michael, 2003, Essentials of Customer Satisfaction, John Wiley \& Sons. 